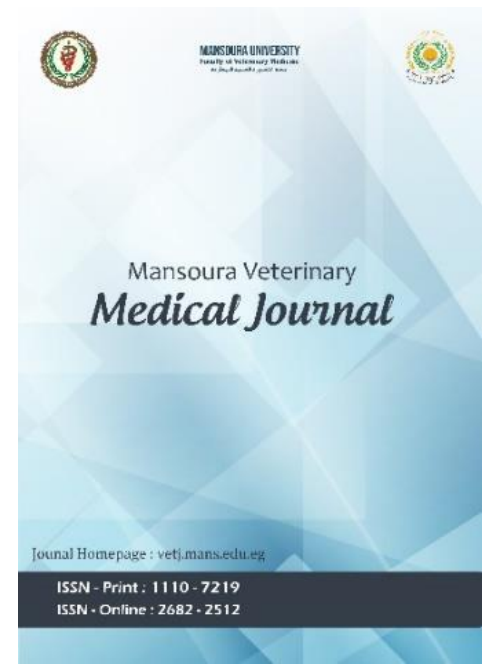

\title{
Protective effect of Nannochloropsis Oculata against mercuric-induced histopathological alterations in the kidney of Nile tilapia
}

Alzahraa Mamdouh, Eman Zahran, Fatma Mohamed, Viola Zaki

To cite this article: Alzahraa Mamdouh, Eman Zahran, Fatma Mohamed, Viola Zaki. Protective effect of Nannochloropsis Oculata against mercuric-induced histopathological alterations in the kidney of Nile tilapia. Mansoura Veterinary Medical Journal 2020; 21, 3: 67-73.

To link to this article: https://doi.org/10.35943/mvmj.2020.21.312

Published online: 29 September 2020

Submit your article to this journal

(D) CrossMark data 


\section{Protective effect of Nannochloropsis Oculata against mercuric-induced histopathological alterations in the kidney of Nile tilapia}

Alzahraa Mamdouh ${ }^{1,2}$, Eman Zahran ${ }^{1}$, Fatma Mohamed $^{2}$, Viola Zaki ${ }^{1}$

${ }^{1}$ Department of Internal Medicine, Infectious and Fish Diseases, Faculty of Veterinary Medicine, Mansoura University, Mansoura 35516, Egypt

${ }^{2}$ Fish Diseases Department National Institute of Oceanography and Fisheries

Received: 03.07. 2020
Revised: 15.07.2020
Accepted: 16.07.2020
Address correspondences to
Alzahraa Mamdouh; Tel:
+201098010602; E-mail:
zahra.ahmed73@yahoo.com

Eman Zahran; Tel: +201211100560; Email: emanzahran@mans.edu.eg

\begin{abstract}
Objective: The present study was designed to evaluate the toxic effect of sublethal concentration of mercuric chloride $\left(0.3 \mathrm{mg} / \mathrm{L} \mathrm{HgCl}_{2}\right)$ on histopathological lesions in the kidney of Nile tilapia (O. niloticus) and the protective effect of microalgae, Nannochloropsis oculata ( $N$. oculata) against the induced tissue alterations for 3 weeks.

Design: Randomized controlled study

Animals: Nile tilapia

Procedures: Fish were randomly assigned to 4 groups, group1: control (basal diet), group 2 (Hg/ exposed to $\mathrm{HgCl}_{2}$ at a dose of $0.3 \mathrm{mg} / \mathrm{L}\left(1 / 4\right.$ of $\left.\mathrm{LC}_{50}\right)$, and fed basal diet), group 3: ( $\mathrm{Hg}+\mathrm{N} 5$, similar to group2, but fed diet supplemented with $\mathrm{N}$. oculata $5 \%$ and group $4(\mathrm{Hg}+\mathrm{N} 10$, similar to group2, but fed diet supplemented with $N$. oculata $10 \%$. Two fish from each aquarium tank (6 fish/group) were sampled at weeks 1, 2, and 3 of the experiment. The posterior kidney was dried out in a graded ethanol series and then embedded in paraffin. Each block of tissue was cut into serial sections ( $5 \mu \mathrm{m}$ thick) and stained with hematoxylin and eosin (H\&E).

Results: Histopathological alterations were induced following mercuric exposure in a time-dependent manner. The kidney showed congestion, hemosiderosis, and hemorrhage with vacuolated tubular epithelium, hyaline droplet degeneration, and necrosis of the tubular epithelium. Supplementation with N. oculata, particularly at $10 \%$, succeeded in alleviating the histopathological induced lesions in the kidney.

Conclusion and clinical relevance: Our findings demonstrate that $\mathrm{HgCl}_{2}$ has nephrotoxic properties that led to severe histopathological alterations in the kidney of Nile tilapia, while dietary supplementation with $N$. oculata was able to alleviate the induced kidney alterations.
\end{abstract}

Keywords: Fish, Heavy metals, Tissue alterations, Microalgae

\section{INTRODUCTION}

Aquaculture is one of the fastest-growing animal-foodproducing sectors [1], which accounts for nearly half of the fish consumed across the world [2]. Tilapia (Oreochromis niloticus), is one of the most important farmed species commercially tra ded worldwide [3]. I t is the most commonly inhabiting and consumed freshwater fish in Africa [4] and the second most farmed fish in the world [5]. Tilapia is commonly us ed as a pollution bioindicator in toxicological investigations [6-9].

In the last few decades, the increase in population growth, massive industrialization, and economic activities have resulted in increased wastes discharge in the aquatic environment with a wi de range of pollutants, including heavy metals $[\mathbf{1 0}, \mathbf{1 1}]$. Mercury $(\mathrm{Hg})$ is one of the most toxic heavy metals entering water sources. It is highly toxic, nonbiodegradable, and persistent in the environment with high potential to bioaccumulate and biomagnify through the food chain [12].

Mercury has been previously reported to induce deleterious damage to many body systems biomarkers, including the immune $[13,14]$, reproductive $[15,16]$, hematological [17-19], and nervous biomarkers [20, 21]. Mercury induces its toxicity mainly through reactive oxygen species (ROS) production, which induces significant damage to the molecular components of proteins, lipids, and DNA of cells resulting in protein degeneration, lipid peroxidation and enzymatic inactivation [22]. Oxidative stress under mercuric toxicity has been numerously investigated [23-26].

Mercury is highly bio-accumulative. Its concentration in marine fish tissues can be significantly elevated to levels up to $100,000 \mathrm{ppm}$ [27]. Organic Mercury has high bioaccumulation potential (up to 5000 -times higher than its concentration in the surrounding water) [28].

ROS induced cellular damage and bi oaccumulation of $\mathrm{Hg}$ eventually result in morphological alterations in fish tissues [11], which on the gross level can be visualized through histopathology. Liver, kidney, and gills are the main ta rget organs for mercury accumulation [4, 29-31] and histopathological alterations [32-34]. Monitoring pathological alterations in tissues and organs dealing with bioaccumulation, biotransformation, and excretion are essential to understand the toxic effects of chemicals in fish [35]. 
Microalgae are autotrophic, photosynthetic microorganisms that have the ability to synthesize biologically complex components such as lipids, proteins, carbohydrates, pigments, and polymers [36]. Most microalgae have a high content of bioactive compounds, including protein, polysaccharides [37], and vitamins such as vitamins $A, C, E, K$, thiamine, pyridoxine, riboflavin, nicotinic acid, biotin, and tocopherol [38, 39]. N. oculata cellular composition is highly rich in bioactive compounds as proteins, polysaccharides and polyunsaturated fatty acids [40] along with its pigment content of violaxanthin with $\beta$-carotene, va ucheriaxanthin, all have antioxidant, anti-inflammatory, antimicrobial and immune-stimulant properties [41] making $N$. oculata a potential dietary supplement with high nutritional and immune stimulant values $[42,43]$. However, their potential impact against the metals induced histopathological damage hasn't yet been investigated.

The present investigation has been carried out to investigate the histopathological alterations in the kidney following mercury intoxication and to elucidate the ameliorative role of the dietary supplementation of the microalgae $N$. oculata against mercury-induced toxicity in Nile tilapia.

\section{MATERIALS AND METHODS}

\subsection{Fish maintenance}

Nile tilapia were procured from a private fish farm in Kafr El-sheik. After 2 weeks a cclimation period, a total of 120 fish (45-50 g) were allocated into 12 glass tanks filled with dechlorinated tap water, in triplicate (10 fish/tank, 30 fish/group). Fish were fed twice daily at $2 \%$ of their body weight. Daily wa ter changes, and removal of fecal matter and wastes were carried out to maintain water quality. Water quality parameters were maintained during the experiment (24 $\pm 2{ }^{\circ} \mathrm{C}$, dissolved oxygen $\left.6.5-7.8 \mathrm{mg} / \mathrm{L}, \mathrm{pH} 7.1-7.3\right)$. The photoperiod was $12 \mathrm{~h}$ light: $12 \mathrm{~h}$ dark.

\subsection{Mercury exposure}

A technical grade mercuric chloride $\left(\mathrm{HgCl}_{2}\right),(99 \%$ purity, El-Gomhoreya Chemical Company Cairo, Egypt) was used to induce fish toxicity. A stock solution of $1000 \mathrm{mg} / \mathrm{L}$ mercury was prepared by dissolving the calculated quantity of $\mathrm{HgCl}_{2}$ in one Littre of distilled water, then the desired concentration in part per million (ppm) was prepared by adding a known volume of the stock solution into the glass aquaria. The control group was handled similarly, adding distilled water without $\mathrm{Hg}$ and under i dentical conditions like other groups.

\subsection{Determination of median lethal concentration $\left(L C_{50}\right)$}

A 96-hr toxicity assay was performed according to Organisation for Economic Co-operation and Development (OECD) 203 guidelines for testing chemicals [44]. A preliminary series of static toxicity tests $(0.3,0.7,1,1.5,3$ $\mathrm{mg} / \mathrm{L} \mathrm{HgCl}_{2}$ ) was a pplied to determine the appropriate range of $\mathrm{Hg}$ toxicity for Nile tilapia. Based on these preliminary tes ts, five concentrations $(0.9,1.2,1.4,1.5$, and $1.7 \mathrm{mg} / \mathrm{L})$ of $\mathrm{HgCl}_{2}$ (each in triplicate, ten fish/tank, $30 \mathrm{fish} / g r o u p$ ) were selected, while the control tank was kept without mercuric exposure and no food was supplied during the experiment to maintain water quality. Test solutions of the chosen concentrations were prepa red by diluting a $1000 \mathrm{mg} / \mathrm{L} \mathrm{HgCl}_{2}$ stock solution. Mortalities were recorded at 24, 48, 72, and $96 \mathrm{hrs}$ of exposure, and dead fish were removed regularly from the aquaria. The obtained data were statistically analyzed using Probit analysis for estimating the $\mathrm{LC}_{50}$ [45] and $1 / 4 \mathrm{LC}_{50}$ was taken as the safe $\mathrm{Hg}$ concentration [46].

\subsection{N. oculata powder}

$N$. oculata dried powder was purchased from the National Research Institute of Cairo, Egypt.

\subsection{Dietpreparation}

Diets composition are presented in Table 1 . All ration components were mixed with oil, and then water was added until a stiff dough is formed. Diet for each treatment was then extruded through a mincer forming strands, and allowed to dry in shadow, broken up, sieved into pellets, and stored in clean dried plastic bags at $4^{\circ} \mathrm{C}$ until use.

\subsection{Experimental design}

Fish were randomly assigned to four groups, namely group1: control (basal diet), group $2\left(\mathrm{Hg} /\right.$ exposed to $\mathrm{HgCl}_{2}$ at a dose of $0.3 \mathrm{mg} / \mathrm{L}\left(1 / 4\right.$ of $\left.L C_{50}\right)$, and fed basal diet), group 3: (Hg+NC5, similar to group2, but fed diet supplemented with N. oculata $5 \%)$ and group $4(\mathrm{Hg}+\mathrm{NC} 10$, similar to group2, but fed diet supplemented with $N$. oculata $10 \%)$. Fish were fed twice daily at $2 \%$ of their body weight for 3 weeks. Water was changed daily up to $80 \%$, with the addition of a new daily stock solution of $\mathrm{HgCl}_{2}$ to the exposed aquaria, waste material, and fecal matter that were siphoned off daily to maintain water quality.

\subsection{Sample collection}

Six fish were sampled from each group ( 2 fish/tank) at weeks 1, 2, and 3 of the experiment. Fish were euthanized with $200 \mathrm{mg} / \mathrm{L}$ of buffered tricaine methanesulfonate (MS222, Argent). The kidney was dissected out of fish and subjected to fixation in neutral buffered formalin for histopathological examination.

\subsection{Histopathological examination}

The posterior kidney was dried out in a graded ethanol series and then embedded in paraffin. Each block of tissue was cut into serial sections ( $5 \mu \mathrm{m}$ thick) and stained with hematoxylin and eosin (H\&E) according to the method described by Bancroft and Gamble [47].

\section{RESULTS}

\subsection{Determination of $L C_{50}$}

$\mathrm{LC}_{50}$ was estimated to be $1.2 \mathrm{mg} / \mathrm{L} \mathrm{Hg}$, and $1 / 4 \mathrm{LC}_{50}(0.3$ $\mathrm{mg} / \mathrm{L}$ ) was taken as safe sublethal $\mathrm{Hg}$ concentration. 
Table 1. Ingredients of basal and experimental diets.

\begin{tabular}{|c|c|c|c|}
\hline $\begin{array}{l}\text { Diet ingredients (g/kg } \\
\text { diet) }\end{array}$ & Control & NC 5 & NC 10 \\
\hline Yellow corn & 126 & 146 & 133 \\
\hline Soya bean meal & 203 & 200 & 190 \\
\hline Fish meal & 200 & 160 & 150 \\
\hline Corn gluten & 10 & 30 & 0 \\
\hline Gelatine & 20 & 20 & 20 \\
\hline Oil & 30 & 35 & 45 \\
\hline Wheat bran & 400 & 350 & 350 \\
\hline $\begin{array}{l}\text { Minerals and vitamins } \\
\text { premix }\end{array}$ & 5 & 5 & 5 \\
\hline Salt & 3 & 3 & 3 \\
\hline Dicalcium phosphate & 1 & 1 & 1 \\
\hline Methionine & 2 & 3.2 & 3.2 \\
\hline Algae & 0 & 50 & 100 \\
\hline \multicolumn{4}{|c|}{$\begin{array}{l}\text { *Trace minerals \& vitamins premixes were prepared to cover the levels } \\
\text { of the microminerals \& vitamins for tilapia fish. Vitamins premix (IU or } \\
\mathrm{mg} / \mathrm{kg} \text { diet); vit. A 5000, Vit. D3 1000, vit. E 20, vit. k3 2, vit. B } 12 \text {, vit. } \\
\mathrm{B} 25 \text {, vit. B6 1.5, vit. B } 120.02 \text {, Pantothenic acid 10, Folic acid 1, Biotin } \\
0.15 \text {, Niacid 30. Mineral mixture (mg/kg diet); Fe } 40, \mathrm{Mn} 80 \text {, Cu } 4 \text {, Zn } \\
\text { 50, I 0.5, Co } 0.2 \text { \& Se } 0.2 \text {. }\end{array}$} \\
\hline
\end{tabular}

\subsection{Histopathology of the kidney}

Kidney at all-time points in the control group showed normal glomeruli, renal tubules, and normal capillary system in the interstitium (Plate.1). Higher magnification of the control kidney showed well developed renal corpuscles with normal glomeruli surrounded by Bowman's capsule, normal renal tubules with contact round or oval nuclei, and characteristic tall columnar epithelium. Also, interstitial hemopoietic tissue appeared normal (Plate.2). However, the kidney of $\mathrm{Hg}$ expos ed group was in-time dependent ma nner, being more severe at Week 2 and 3 compared to week 1 , where congestion and hemorrhage in the interstitial tissue were observed at week 1 , but, more progressive lesion, including congestion and necrosis, were more evident at week 2 and 3 (Plate.1). Higher magnification of the kidney at week 1 showed congestion, hemosiderosis, and hemorrhage with vacuolated tubular epithelium. The lesions became more progressive than earlier at weeks 2 and 3 showing vacuolated tubular epithelium, hyaline droplet degeneration, and necrosis of the tubular epithelium at week two while, at week three the kidney showed vacuolated tubular epithelium with edema, hemorrhage, hemosiderosis and severe necrosis (Plate.2)

Supplementation with $N$. oculata at $5 \%$ showed less severe lesions in the kidney, including congestion in the interstitial tissue at weeks 1 and 2 only (Plate.1). Higher magnification of the kidney showed vacuolated tubular epithelium and congestion in the interstitial tissue during the first two weeks, while at week 3, the kidney showed vacuolated tubular epithelium and hyaline droplet degeneration of the tubular epithelium (Plate.2). Noteworthy that the kidney of the fish supplemented with $N$. oculata at $10 \%$ showed mil der degrees of congestion at weeks 1 and 2 (Plate.1). Higher magnification of renal sections showed milder degrees of congestion with tubular degeneration and hyaline droplet degeneration (Plate.2).

\section{DISCUSSION}

Histopathological examination is one of the most es sential tools in the diagnosis of heavy metals toxicity. Heavy metals usually accumulate in specific target organs such as liver, kidney, and gills [4, 29-31], and their presence causes tissue da mage that could be emphasized by histopathological examination [11].

The kidney plays a vital role in maintaining internal body stability regarding electrolytes, water balance, and the elimination of nitrogenous metabolites. It is the leading trophic site for mercuric chloride bioaccumulation in chronic exposures [48]. The kidney has been described as a target organ affected by mercuric toxicity.

The kidney of fish from mercury exposed group was severely damaged showing congestion, hemosiderosis, hemorrhage, and vacuolated tubular epithelium at weak one and the lesions became more progressive at weak 2 and 3 showing vacuolated tubular epithelium, hyaline droplet degeneration and necrosis of the tubular epithelium at weak two, while at weak three the kidney showed vacuolated tubular epithelium with edema, hemorrhage, hemosiderosis, and severe necrosis.

Mercury has a higher affinity towards sulfhydryl groups on the cell membrane, causing a disturbance in active trans port and cell functions [48]. Therefore, the kidney has been reported to be target organs for mercury bioaccumulation and increased concentration [48-50]. Al these reas ons contribute to the damage induced by mercury in the function and morphology of the kidney. 


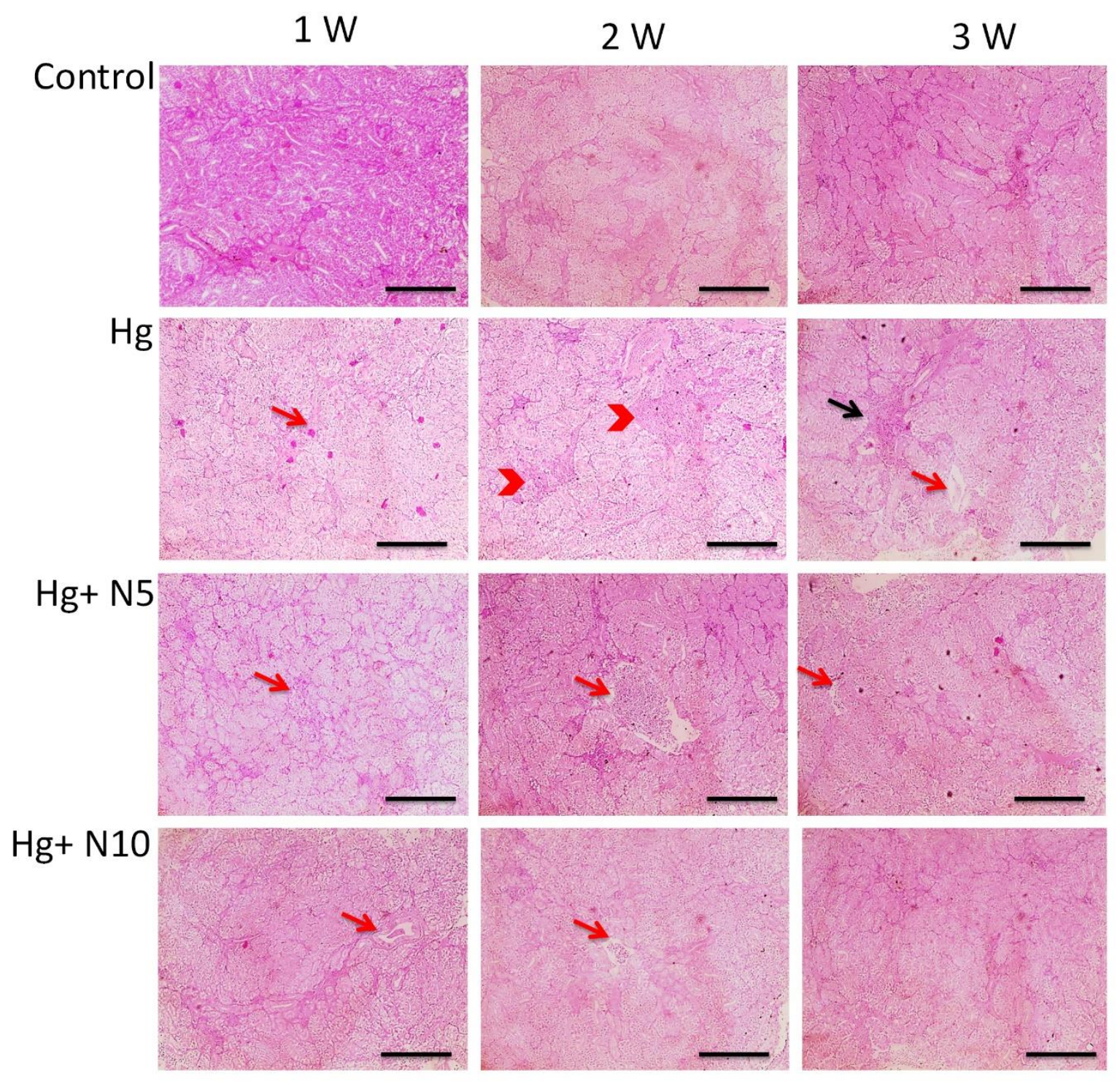

Plate.1. Microscopic pictures of H\&E stained sections of kidneys showing normal glomeruli, tubules, hemopoietic tissue (control group) at weak 1 (column A), 2 (column B) and 3 (column C). Renal sections from Hg exposed group show congestion (red arrows) and hemorrhage (red arrowheads) in interstitial tissue at weak 1 (column A) and weak 2 (column B), congestion (red arrows) and necrosis (black arrows) at weak 3 (column C). Renal sections from $\mathrm{Hg}+\mathrm{N} 5$ show congestion in interstitial tissue (red arrows) at weak 1 (column A) and 2 (column B) only. Milder degrees of conge stion (red arrows) appear in renal sections from $\mathrm{Hg}+\mathrm{N} 10$ at weak 1 (column A) and 2 (column B) only. X: 100 bar 100.

Kidney damage on the histopathological level was also reported in Nile tilapia exposed to $2 \mu \mathrm{g} / \mathrm{g} \mathrm{HgCl}_{2}$ through semistatic exposure where the kidney showed hydropic degeneration, necrosis in the tubular epithelium with hyaline droplets and deposition of the pleomorphic crystal [51]. Additionally, the kidney of Indian Major Carp (Labeo rohita) exposed to $0.1 \mathrm{mg} / \mathrm{L} \mathrm{HgCl}_{2}$ for 30 days showed des quamated epithelium, shrinked glomerulus, necrosis and pyknosis of the nuclei with hypertrophied cells in renal tubules [48], while the kidney of juvenile zebra seabream exposed to $2 \mu \mathrm{g} / \mathrm{L} \mathrm{HgCl}_{2}$ for 28 days showed vacuolar and hydropic degeneration of tubular epithelium and pigment deposits around the tubules.
Large necrotic areas in posterior kidney and eosinophilic material filled the tubular lumen [50].

In our study, supplementation with $N$. oculata, particularly at $10 \%$, was able to diminish histopathological alterations in the kidney. This might be attributed to its bioactive constituents that have antioxidant, immunostimulant, and metal chelating a ctivities, particularly viol axanthin and provitamin A ( $\beta$-carotene [52], $\alpha$-linolenic acid [40], and content of complex anionic sulfated heteropolysaccharides, particularly mannans and sulfated heterorhamnan [53-56]. 

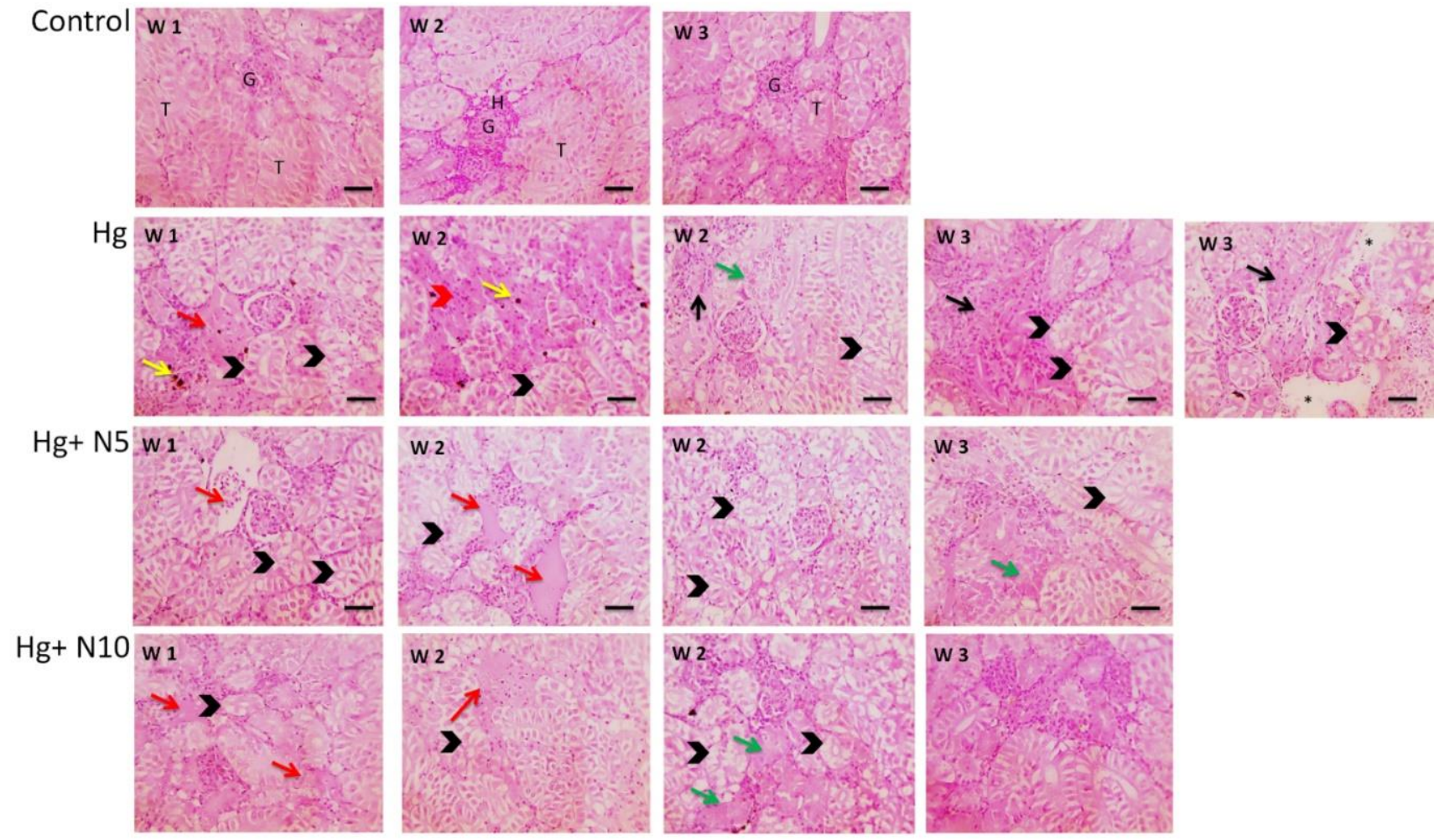

Plate.1. Hg exposed group show congestion (red arrows), hemosiderosis (yellow arrows) with vacuolated tubular epithelium (black arrowheads) at weak 1 , vacuolated tubular epithelium (black arrowheads), hyaline droplet degeneration (green arrows) and necrosis (black arrows) at weak 2, vacuolated tubular epithelium (black arrowheads), edema (asterisks), hemorrhage (red arrowheads), hemosiderosis (yellow arrows), necrosis (black arrows) at weak 3. Renal sections from $\mathrm{Hg}+\mathrm{N} 5$ after show vacuolated tubular epithelium (black arrowheads), congestion in interstitial tissue (red arrows) at weak 1 and 2, vacuolated tubular epithelium (black arrowheads) and hyaline droplet degeneration (green arrows) at weak 3. Milder degrees of congestion (red arrows) appear in renal sections from $\mathrm{Hg}+\mathrm{N} 5$ with tubular degeneration (black arrowheads) and hyaline droplet degeneration (green arrows) at weak 1 and 2 only. X: 100 bar 100.

The presence of phenolics [57] and flavonoid compounds [55], ca rotenoids, na mely, vi olaxanthin, astaxanthin, lutein, zeaxanthin, chlorophylls $a$ and $b$ and $\beta$-carotene contributes at a major extent to the antioxidant activity of $N$. oculata [53] Phenolic compounds and flavonoids are electron donor substances that exhibit a n essential role in reduction capacity [58] and antioxidant activity [55]. They also have metal chelating activities $[53,55]$, which help to lower $\mathrm{Hg}$ accumulation and the resulting damage. Also, N. oculate have high cellular content of $\omega-3$ poly unsaturated fatty acids (PUFAs, $\alpha$-linolenic (ALA, C18:3 $\omega 3$ ) and eicosapentaenoic (EPA, C20:5 w3)) which constitute about $32 \%$ of the total fatty acids [40], along with $\omega 6$ fatty a cids. Thes e components exert vital action in the activation of the immune system; they act as ligands to immune cells [59].

Ameliorating effects of microalgae against his topathological alterations induced by pollutants have been reported on many occasions, where dietary supplementation with $2 \%$ Chlorella pyrenoidosa (C. pyrenoidosa) was able to reduce histopathological alterations in the kidney of Prussian carp (Carassiusgibelio) exposed to $10 \mathrm{mg} / \mathrm{LCdCl}_{2}$ for 21 days [60]. Similarly, C. vulgaris decreased the intensity of the histological lesions in the kidney of Nile tilapia intoxicated with sodium arsenite $\left(\mathrm{NaASO}_{2}\right.$ ) at $7 \mathrm{mg} / \mathrm{L}$ for 21 days [61]. Additionally, dietary supplementation with Thunbergia laurifolia leaf at a dose of 0.2 and $2 \mathrm{mg}$ extract/g food managed to decrea se morphological alterations in the kidney of Nile tilapia exposed to $45 \mathrm{mg} / \mathrm{L}$ of lead nitrate $\left(\mathrm{Pb}\left(\mathrm{NO}_{3}\right)_{2}\right)$ [62].

\section{Conclusion}

Mercuric has nephrotoxic properties, and its toxicity elicited severe damage and histopathological alterations in the kidney of Nile tilapia, while dietarys upplementation with $N$. oculate succeeded in ameliorating mercuric induced toxicity and relieved the histopathological lesions in the kidney, particularly at level of $10 \%$.

\section{Conflict of interest}

Authors declare that they have no conflict of interest

\section{Acknowledgment}

This research was supported by Laboratory of Fish Diseases, Department of Internal Medicine, Infections and Fish Disease, Faculty of Veterinary Medicine; and Animal Health Research Institute

\section{Author' contributions}

A.M. performed the experiment and drafted the MS; EZ. reviewed and edited MS; E.Z. F.M. and V.Z. supervised the 
whole research work.

\section{REFERENCES}

[1] Allison EH. Aquaculture, fisheries, poverty and food security. Worldfish, working paper $\quad-65, \quad 2011$ http://aquaticcommons.org/7517/1/WF_2971.pdf

[2] Ottinger M, Clauss K, Kuenzer C. Aquaculture: relevance, distribution, impacts and spatial assessments-a review. Ocean \& Coastal Management. https://doi. org/10.1016/j. ocecoaman.2015.10.015

[3] Wang M, Lu M. Tilapia polyculture: a global review. Aquacult Res. 2016;47:2363-74. https://doi.org/10.1111/are.12708

[4] Al-Asgah NA, Abdel-Warith A-WA, Younis E-SM, Allam HY. Haematological and biochemical parameters and tissue accumulations of cadmium in Oreochromis niloticus exposed to various concentrations of cadmium chloride. Saudi J Biol Sci. 2015;22:543-50. https://doi. org/10.1016/j.sjbs.2015.01.002

[5] FAO F. Agriculture Organization, 2014. Livestock Primary Food and Agriculture Organization of the United Nations. 2016.

[6] Alaa G. Biomarkers in Nile tilapia Oreochromis niloticus niloticus (Linnaeus, 1758) to assess the impacts of river Nile pollution: bioaccumulation, biochemical and tissues biomarkers. J Environ Prot (Irvine, Calif). 2012;2012.

[7] Omer SA, Elobeid MA, Fouad D, Daghestani MH, Al-Olayan EM, Elamin $\mathrm{MH}$, et al. Cadmium bioaccumulation and toxicity in tilapia fish (Oreochromis niloticus). J Anim Vet Adv. 2012;11:1601-6. https://doi. org/10.3923/javaa.2012.1601.1606

[8] Sayed E, Shokr E. Effect of zinc on hematology and biochemistry of Nile Tilapia. 2015;2015:1943-50.

[9] Pei J, Zuo J, Wang X, Yin J, Liu L, Fan W. The Bioaccumulation and Tissue Distribution of Arsenic Species in Tilapia. Int J Env Res Public Health. 2019;16:757. https://doi. org/10.3390/ijerph16050757

[10] Okoro HK, Fatoki OS, Adekola FA, Ximba BJ, Snyman RG. A review of sequential extraction procedures for heavy metals speciation in soil and sediments. 2012. https://doi. org/10.4172/scientificreports. 181

[11] Chavan V, Muley D. Effect of heavy metals on liver and gill of fish Cirrhinus mrigala. International Journal of Current Microbiology and Applied Sciences. 2014;3:277-88.

[12] Cappello T, Brandão F, Guilherme S, Santos MA, Maisano M, Maucen A, et al. Insights into the mechanisms underlying mercury-induced oxidative stress in gills of wild fish (Liza aurata) combining $1 \mathrm{H}$ NMR metabolomics and conventional biochemical assays. Science of the Total Environment. 2016;548:13-24. https://doi.org/10.1016/j.scitotenv.2016.01.008

[13] Aboud O. Impact of pollution with lead, mercury and cadmium on the immune response of Oreochromis niloticus. NY Sci J. 2010;3:9-16.

[14] Begam M, Sengupta M. Immunomodulation of intestinal macrophages by mercury involves oxidative damage and rise of pro-inflammatory cytokine release in the fresh water fish Channa punctatus Bloch. Fish Shellfish Immunol.

2015;45:378-85 https://doi. org/10.1016/j.fsi.2015.04.017

[15] Dietrich GJ, Dietrich M, Kowalski RK, Dobosz S, Karol H, Demianowicz W, et al. Exposure of rainbow trout milt to mercury and cadmium alters sperm motility parameters and reproductive success. Aquat Toxicol. 2010;97:277-84. https://doi.org/10.1016/j. aquatox.2009.12.010

[16] Burch JB, Robb SW, Puett R, Cai B, Wilkerson R, Karmaus W, et al. Mercury in fish and adverse reproductive outcomes: results from South Carolina. International journal of health geographics. 2014;13:30. https://doi. org/10.1186/1476-072X-13-30

[17] El-Boshy M, Taha R. Effects of Mercuric Chloride on the Immunological, Hematological, Biochemical Parameters and Diseases Resistance of Nile Tilapia Challenged with Aeromnas hydrophila. Nature and Science. 2011;9.

[18] Elseady $Y$, Zahran E. Ameliorating effect of $\beta$-carotene on antioxidant response and hematological parameters of mercuric chloride toxicity in Nile tilapia (Oreochromis niloticus). Fish Physiol Biochem. 2013;39:1031-41. https://doi. org/10.1007/s10695-012-9760-8

[19] Swetha S, Pramod Kiran R. STUDIES ON THE HAEMATOLOGICAL PARAMETERS OF ANABAS TESTUDINEUS (BLOCH, 1792) AFTER LONG
TERM EXPOSURE TO METHYL MERCURY. Journal of Aquatic Biology \& Fisheries| Vol. 2016;4:172-5.

[20] Scheuhammer A, Braune B, Chan HM, Frouin H, Krey A, Letcher R, et al. Recent progress on our understanding of the biological effects of mercury in fish and wildlife in the Canadian Arctic. Sci Total Environ. 2015;509:91-103. https://doi. org/10.1016/j.scitotenv.2014.05.142

[21] Pereira P, Puga S, Cardoso V, Pinto-Ribeiro F, Raimundo J, Barata M, et al. Inorganic mercury accumulation in brain following waterborne exposure elicits a deficit on the number of brain cells and impairs swimming behavior in fish (white seabream-Diplodus sargus). Aquat Toxicol. https://doi.org/10.1016/j.aquatox.2015.11.031

[22] Huang W, Cao L, Ye Z, Lin L, Chen Q, Dou S. Tissue-specific bioaccumulation and oxidative stress responses in juvenile Japanese flounder (Paralichthys olivaceus) exposed to mercury. Chin J Oceano Limnol. 2012;30:569-79. https://doi.org/10.1007/s00343-012-1210-z

[23] Monteiro DA, Rantin FT, Kalinin AL. Inorganic mercury exposure: toxicological effects, oxidative stress biomarkers and bioaccumulation in the tropical freshwater fish matrinxã, Brycon amazonicus (Spix and Agassiz, 1829). Ecotoxicology. 2010;19:105. https://doi.org/10.1007/s10646-009-0395-1

[24] Kong X, Wang S, Jiang H, Nie G, Li X. Responses of acid/alkaline phosphatase, lysozyme, and catalase activities and lipid peroxidation to mercury exposure during the embryonic development of goldfish Carassius auratus. Aquat Toxicol. 2012;120:119-25. https://doi.org/10.1016/j. aquatox.2012.05.005

[25] Zhang Q-F, Li Y-W, Liu Z-H, Chen Q-L. Exposure to mercuric chloride induces developmental damage, oxidative stress and immunotoxicity in zebrafish embryos-larvae. Aquat Toxicol. 2016;181:76-85. https://doi.org/10.1016/j.aquatox.2016.10.029

[26] Ren Z, Liu J, Huang W, Cao L, Cui W, Dou S. Antioxidant defenses and immune responses of flounder Paralichthys olivaceus larvae under methylmercury exposure. Comparative Biochemistry and Physiology Part C: Toxicology \& Pharmacology. 2019;225:108589. https://doi.org/10.1016/j.cbpc. 2019.108589

[27] Maheswaran R, Devapaul A, Muralidharan S, Velmurugan B, Ignacimuthu S. Haematological studies of fresh water fish, Clarias batrachus (L.) exposed to mercuric chloride. 2008.

[28] Holmes P, James K, Levy L. Is low-level environmental mercury exposure of concern to human health? Sci Total Environ. 2009;408:171-82. https://doi.org/10.1016/j.scitotenv.2009.09.043

[29] Al-Balawi HFA, Al-Akel AS, Al-Misned F, Suliman EAM, Al-Ghanim KA, Mahboob S, et al. Effects of sub-lethal exposure of lead acetate on histopathology of gills, liver, kidney and muscle and its accumulation in these organs of Clarias gariepinus. Braz Arch Biol Technol. 2013;56:293302. https://doi.org/10.1590/S1516-89132013000200015

[30] Abarshi MM, Dantala EO, Mada SB. Bioaccumulation of heavy metals in some tissues of croaker fish from oil spilled rivers of Niger Delta region, Nigeria. Asian Pacific Journal of Tropical Biomedicine. 2017;7:563-8. https://doi.org/10.1016/j.apjtb. 2017.05.008

[31] Li M, Zhu X, Tian J, Liu M, Wang G. Bioaccumulation, oxidative stress, immune responses and immune-related genes expression in northern snakehead fish, Channa argus, exposure to waterborne selenium. Mol Biol Rep. 2019;46:947-55. https://doi.org/10.1007/s11033-018-4550-8

[32] Kaoud HA, Mahran KM, Rezk A, Khalf MA. Bioremediation the toxic effect of mercury on liver histopathology, some hematological parameters and enzymatic activity in Nile tilapia, Oreochromis niloticus. Researcher. 2012;4:60-70.

[33] Jasim MA, Sofian-Azirun M, Yusoff I, Rahman MM. Bioaccumulation and histopathological changes induced by toxicity of mercury $(\mathrm{HgCl} 2)$ to tilapia fish Oreochromis niloticus. Sains Malays. 2016;45:119-27.

[34] Waheed R, El Asely AM, Bakery H, El-Shawarby R, Abuo-Salem M, Abdet Aleem $\mathrm{N}$, et al. Thermal stress accelerates mercury chloride toxicity in Oreochromis niloticus via up-regulation of mercury bioaccumulation and HSP70 mRNA expression. Sci Total Environ. 2020;718:137326. https://doi.org/10.1016/j.scitotenv.2020.137326

[35] Vergilio C, Carvalho C, DE MELO EJT. Accumulation and histopathological effects of mercury chloride after acute exposure in tropical fish Gymnotus carapo. 2012

[36] de Morais MG, Vaz BdS, de Morais EG, Costa JAV. Biologically Active Metabolites Synthesized by Microalgae. BioMed Research International. https://doi. org/10.1155/2015/835761
2015;2015:835761. 
[37] Mohamed ZA. Polysaccharides as a protective response against microcystin-induced oxidative stress in Chlorella vulgaris and Scenedesmus quadricauda and their possible significance in the aquatic ecosystem. Ecotoxicology. 2008;17:504. https://doi.org/10.1007/s10646-008-0204-2

[38] Chew KW, Yap JY, Show PL, Suan NH, Juan JC, Ling TC, et al. Microalgae biorefinery: high value products perspectives. Bioresour Technol. 2017;229:53-62. https://doi.org/10.1016/j.biortech.2017.01.006

[39] Khan MI, Shin JH, Kim JD. The promising future of microalgae: current status, challenges, and optimization of a sustainable and renewable industry for biofuels, feed, and other products. Microbial cell factories. 2018;17:36. https://doi.org/10.1186/s12934-018-0879-x

[40] Matos ÂP, Feller R, Moecke EHS, de Oliveira JV, Junior AF, Derner RB, et al. Chemical characterization of six microalgae with potential utility for food application. J Am Oil Chem Soc. 2016;93:963-72. https://doi. org/10.1007/s11746-016-2849-y

[41] Bule MH, Ahmed I, Maqbool F, Bilal M, Iqbal H. Microalgae as a source of high-value bioactive compounds. Front Biosci(Sch Ed). 2018;10:197216. https://doi. org/10.2741/s509

[42] Gbadamosi OK, Lupatsch I. Effects of dietary Nannochloropsis salina on the nutritional performance and fatty acid profile of Nile tilapia, Oreochromis niloticus. Algal research. 2018;33:48-54 https://doi.org/10.1016/j.algal.2018.04.030

[43] Md A, Jin F, Jeong U-C, Choi J-K, Lee D-I, Yu HS, et al. Effects of Nannochloropsis concentration in diet on growth, survival and antiinflammatory cytokine (Interleukin-10) production of the sea cucumber Apostichopus japonicus. Turkish Journal of Fisheries and Aquatic Sciences. 2018;18:567-75. https://doi.org/10.4194/1303-2712V18 408

[44] Fish ATT. OECD Guideline for Testing of Chemicals. OECD-Organisation for Economic Co-operation and Development; 2000.

[45] Finney D. Probit Analysis., 3rd edn.(Cambridge University Press: Cambridge, UK.). 1971.

[46] Sprague J. Measurement of pollutant toxicity to fish-III: Sublethal effects and "safe" concentrations. Water Res. 1971;5:245-66. https://doi.org/10.1016/0043-1354(71)90171-0

[47] Bancroft JD, Gamble M. Theory and practice of histological techniques. In: ed. t, editor.: London: Churchill Livingstone; 2008.

[48] Ghosh D, Mandal DK. Histopathological effects and bioaccumulation of mercury in the kidney of an indian major carp, Labeo rohita (Hamilton). Bull Environ Contam Toxicol. 2012;89:479-83. https://doi.org/10.1007/s00128-012-0743-3

[49] Lee J-W, De Riu N, Lee S, Bai SC, Moniello G, Hung SS. Effects of dietary methylmercury on growth performance and tissue burden in juvenile green (Acipenser medirostris) and white sturgeon (A. transmontanus). Aquat Toxicol. 2011;105:227-34. https://doi.org/10.1016/j. aquatox.2011.06.013

[50] Branco V, Canário J, Lu J, Holmgren A, Carvalho C. Mercury and selenium interaction in vivo: effects on thioredoxin reductase and glutathione peroxidase. Free Radical Biol Med. 2012;52:781-93. https://doi.org/10.1016/j.freeradbiomed.2011.12.002

[51] Kaewamatawong T, Rattanapinyopituk K, Ponpornpisit A, Pirarat N, Ruangwises S, Rungsipipat A. Short-term exposure of Nile Tilapia (Oreochromis niloticus) to mercury: histopathological changes, mercury bioaccumulation, and protective role of metallothioneins in different exposure routes. Toxicol Pathol. 2013;41:470-9. https://doi. org/10.1177/0192623312457269

[52] Al-Hoqani U, Young R, Purton S. The biotechnological potential of Nannochloropsis. Perspectives in Phycology. 2016. https://doi. org/10.1127/pip/2016/0065

[53] Custódio L, Soares F, Pereira H, Rodrigues MJ, Barreira L, Rauter AP, et al. Botryococcus braunii and Nannochloropsis oculata extracts inhibit cholinesterases and protect human dopaminergic SH-SY5Y cells from H2O2-induced cytotoxicity. J Appl Phycol. 2015;27:839-48. https://doi.org/10.1007/s10811-014-0369-4

[54] Hafsa MB, Ismail MB, Garrab M, Aly R, Gagnon J, Naghmouchi K. Antimicrobial, antioxidant, cytotoxic and anticholinesterase activities of water-soluble polysaccharides extracted from microalgae Isochrysis galbana and Nannochloropsis oculata. Journal of the Serbian Chemical Society. 2017;82:509-22. https://doi. org/10.2298/JSC161016036B

[55] Ebrahimzadeh MA, Khalili M, Dehpour AA. Antioxidant activity of ethyl acetate and methanolic extracts of two marine algae, Nannochloropsis oculata and Gracilaria gracilis-an in vitro assay. Brazilian Journal of
Pharmaceutical Sciences. 2018;54. https://doi.org/10.1590/s217597902018000117280

[56] Pandeirada CO, Maricato É, Ferreira SS, Correia VG, Pinheiro BA, Evtuguin DV, et al. Structural analysis and potential immunostimulatory activity of Nannochloropsis oculata polysaccharides. Carbohydrate polymers.

2019;222:114962 https://doi.org/10.1016/j.carbpol.2019.06.001

[57] Hajimahmoodi M, Faramarzi MA, Mohammadi N, Soltani N, Oveisi MR, Nafissi-Varcheh N. Evaluation of antioxidant properties and total phenolic contents of some strains of microalgae. J Appl Phycol. 2010;22:43-50. https://doi. org/10.1007/s10811-009-9424-y

[58] Sharma P, Gujral HS, Singh B. Antioxidant activity of barley as affected by extrusion cooking. Food Chem. 2012;131:1406-13. https://doi.org/10.1016/j.foodchem.2011.10.009

[59] Abdelhamid FM, Elshopakey GE, Aziza AE. Ameliorative effects of dietary Chlorella vulgaris and $\beta$-glucan against diazinon-induced toxicity in Nile tilapia (Oreochromis niloticus). Fish Shellfish Immunol. 2020;96:213-22. https://doi.org/10.1016/j.fsi.2019.12.009

[60] Nicula M, Dumitrescu G, Pacala N, Stef L, Tulcan C, Dragomirescu M, et al. Garlic, Cilantro and Chlorella's Effect on Kidney Histoarchitecture Changes in Cd-intoxicated Prussian carp (Carassius gibelio). Scientific Papers Animal Science and Biotechnologies. 2016a;49:168-77.

[61] Zahran E, Awadin W, Risha E, Khaled AA, Wang T. Dietary supplementation of Chlorella vulgaris ameliorates chronic sodium arsenite toxicity in Nile tilapia Oreochromis niloticus as revealed by histopathological, biochemical and immune gene expression analysis. Fish Sci. 2019;85:199-215. https://doi.org/10.1007/s12562-018-1274-6

[62] Palipoch S, Jiraungkoorskul W, Tansatit T, Preyavichyapugdee N, Jaikua W, Kosai P. Protective efficiency of Thunbergia laurifolia leaf extract against lead (II) nitrate-induced toxicity in Oreochromis niloticus. Journal of Medicinal Plants Research. 2011;5:719-28. 